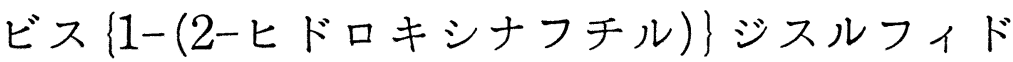 \\ 存在下におけるアビェチン酸の \\ 不均化及び開裂反応
}

\author{
井上良計・石上雅 久 \\ 播磨化成工業株式会社中央研究所（加古川市野口町水足）
}

\section{Disproportionation and Cleavage Reaction of Abietic Acid in the Presence of Bis [1-(2-hydroxynaphthyl) $]$ disulfide}

\author{
Yoshikazu Inoue, and Masahisa Ishigami \\ Harima Chemicals Inc. (Mizuashi, Noguchi, Kakogawa)
}

\begin{abstract}
Disproportionation and cleavage reaction of abietic acid by arylthiol was studied. Bis $\{1-(2$-hydroxy= naphthyl) $\}$ disulfide (BNDS) was an excellent catalyst among the several catalysts. When BNDS was used as the catalyst, disproportionation reaction of abietic acid proceeded predominantly at high tempe= ratures, but at low temperatures cleavage reaction proceeded and secodehydroabietic acid was mainly produced.

When abietic acid was treated with $1 \mathrm{w} t \%$ BNDS for $14 \mathrm{~h}$ at $200^{\circ} \mathrm{C}$, reaction products were seco= dehydroabietic acid $(54.8 \%)$, deisopropyldehydroabietic acid $(11.7 \%)$, dehydroabietic acid $(11.5 \%)$, and abietic acid $(3.6 \%)$. It was found that secodehydroabietic acid was obtained in reasonable yield at low temperature $\left(200^{\circ} \mathrm{C}\right)$.
\end{abstract}

\section{1 緒言}

アビエチン酸（Fig-1 $[\mathbf{V}]$ )の不均化反応については

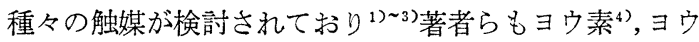
化鉄) 鉄ペンタカルボニル6) 触媒としてアビエチン酸 の不均化反応について検討して来た。ヨウ素触媒を使用 した場合副反応生成物としてセコデヒドロアビエチン酸 が最大 $25 \%$ も生成する事が明らかになっだ。

セコデヒドロアビエチン酸 (Fig.-1 $[\mathbf{I}],[\mathbf{I I}])$ はレボ ピマル酸とアルカリの加熱反応により生成するこ之が, Takeda らによって報告されており ${ }^{8)}$ その後 Zinkel らに よってトール油の中間留分にも含まれることが明らかに

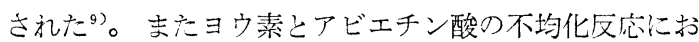
いても生成することが確認され4)，アリールチオール触 媒によるロジンの不均化反応中にも生成する门。

アリールチオールの不均化反応への適用はロジンに対 してなされており，ピマル酸，イソピマル酸などの不純 物が含まれるため反応の詳細な検討はなされていない。 Thorpe らうの目的はロジンを $250 \sim 275^{\circ} \mathrm{C}$ の範国で不 均化しセコデヒドロアビエチン酸を 5 〜 $10 \%$ 程度生成さ
せることにより非結晶性の不均化ロジンを製造すること にある。著者らはアリールチオールを触媒としてアビエ チン酸の不均化反応について詳細に検討し, 反応条件に より不均化反応よりも開裂反応が主となりセコデヒドロ アビエチン酸が著しく増加することが明らかになったの で報告する。

\section{2 実験}

\section{$2 \cdot 1$ 試料}

アビエチン酸は前報は) と同様中国産ガムロジンより精 製した（純度 94\% $\mathrm{GLC}$ )。トルエンー3,4-ジチオール（T DT), チオサリチル酸 (TSA), 1-ドデカンチオール (DT) は市販試薬を使用し，チオビスフェノールは住友 化学スミライザーWX を使用した。ビス $\{1$-(2-ヒドロ キシナフチル)\} ジスルフィド (BNDS) は Jusaらの方 法汇従って合成した ${ }^{10)}\left(\mathrm{mp} 167 \sim 169^{\circ} \mathrm{C}\right.$ 文献值 $\left.169^{\circ} \mathrm{C}\right)$ 。 ビス $\{1-(2$-ヒドロキシナフチル)\} スルフィド (BNS) は Onufrowicz の方法に従って合成した ${ }^{11)}$ (mp 218〜 $219^{\circ} \mathrm{C}$, 文献值 $215^{\circ} \mathrm{C}$ )。

\section{2 反応}


アビエチン酸 $20 \mathrm{~g}$ を $50 \mathrm{ml}$ 四っロフラスコに仕込 み、各触媒を所定量添加した後加熱し所定の温度まで昇 温後, $0.5,1.0,2.0,4.0 \mathrm{~h}$ でサンプルを採取しジアゾ メタンでメチル化後 GLC 分析した。生成物の同定は GC-MS により行った。各質量スペクトル汢前報4で単 離したもの上よく一致した。

\section{3 結果および考察}

\section{$3 \cdot 1$ 種々のチオールの触媒効果}

反応温度 $200^{\circ} \mathrm{C}, 250^{\circ} \mathrm{C}$ における各種チオールの不均 化反応に対する触媒効果の比較を行った。反応 $4 \mathrm{~h}$ での 主な生成物の GLC 分析の結果を Table-1 に示す。ま た主な反忘生成物の構造を Fig.-1 に示す。

$200^{\circ} \mathrm{C}$ では BNDS および BNS 以外は, ほとんど触 媒効果を示さない。BNDS の触媒作用は主にアビエチ ン酸骨格のB環の開裂によるセコデヒドロアビエチン酸 の生成に有効であり、アビエチン酸系成分の減少量の約 半分に相当する $37.7 \%$ のセコデヒドロアビエチン酸が 生成している。これに対し不均化反応は起こりにくくデ ヒドロアビエチン酸は $13 \%$ 生じているがジヒドロアビ エチン酸注全異性体合わせて $4.4 \%$ しか生じておらずむ しろ脱水素反応とみなすべきである。

$250^{\circ} \mathrm{C}$ では TDT が不均化触媒として有效に作用し ている。アビエチン酸の残存量は $9.5 \%$ と BNDS, BNS に比較して多いけれ，ど不均化反応生成物であるデヒド口 アビエチン酸とジヒドロアビエチン酸の量は BNDS お よび BNS より 10\% 以上も多く生じている。これは TDT が不均化反応に有効であるのに対し BNDS およ び BNS がB環の開裂反応に有効であることを示してい る。 $250^{\circ} \mathrm{C}$ で TSA, WX はある程度の触媒作用を示し ているが DT ではほ上んど触媒作用を示さない。不均化

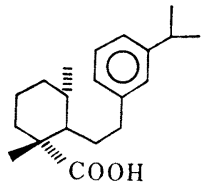

( I )

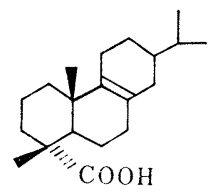

(III)

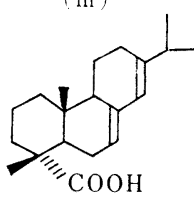

( V )

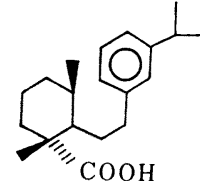

(II)

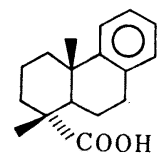

(IV)

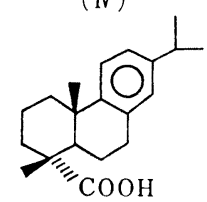

( VI)
Fig.-1 Structure reaction product.

又は脱水素に有効なチオールは脂肪族のもの上りも芳香 環に直接結合しているものが効果が大であるといえる。

\subsection{BNDS の触媒作用}

前述のように BNDS がB環の開裂反応の触媒として 特に低温において有効であることが認められたので，こ の点についてさらに詳細に検討するため, $200^{\circ} \mathrm{C}, 250^{\circ} \mathrm{C}$, $290^{\circ} \mathrm{C}$ において触媒量を変えて反応を行った。結果を

Table-2 に示す。結果から反応温度が低いほどセコデ ヒドロアビエチン酸の生成する割合が高くなっているこ とが明らかである。触媒 $1 \mathrm{wt} \%$ における $200^{\circ} \mathrm{C}, 250^{\circ} \mathrm{C}$, $290^{\circ} \mathrm{C}$ での反応したアビエチン酸量（反応前のアビエチ ン酸より残存するアビエチン酸, パラストリン酸, ネオ アビエチン酸の量を差し引いた值）に対する生成したセ

Table-1 Disproportionation reaction with several catalysts.

\begin{tabular}{|c|c|c|c|c|c|c|c|c|c|c|c|c|}
\hline & 1 & 2 & 3 & 4 & 5 & 6 & 7 & 8 & 9 & 10 & 11 & 12 \\
\hline Catalyst & BNDS & BNS & TDT & T S A & WX & $\mathrm{DT}$ & BNDS & BNS & TDT & T S A & WX & $\mathrm{DT}$ \\
\hline Catalyst(wt\%) & 1 & 1 & 1 & 1 & 1 & 1 & 1 & 1 & 1 & 1 & 1 & 1 \\
\hline Reaction Temp. & 200 & 200 & 200 & 200 & 200 & 200 & 250 & 250 & 250 & 250 & 250 & 250 \\
\hline Reation time & 4 & 4 & 4 & 4 & 4 & 4 & 4 & 4 & 4 & 4 & 4 & 4 \\
\hline $\operatorname{secoDehAb}(I)^{* 1}$ & 23.3 & 10.6 & 2.1 & 一 & - & 一 & 22.2 & 20.8 & 7.9 & 1.6 & 1.1 & 0.6 \\
\hline secoDehAb(II ) & 14.4 & 6.9 & 1.3 & - & - & 一 & 18.1 & 17.6 & 7.7 & 2.3 & 2.2 & 0,6 \\
\hline secoDehAb(total) & $(37.7)$ & $(17.5)$ & $(3.4)$ & 一 & - & 一 & $(40.3)$ & $(38.4)$ & $(15.6)$ & (3.9) & (3.3) & $(1.2)$ \\
\hline $\operatorname{DihAb}(\text { total })^{* 2}($ III $)$ & 4.4 & 2.9 & - & 一 & 一 & 一 & 10.0 & 10.3 & 13.3 & 10.4 & 9.9 & 5.0 \\
\hline $\begin{array}{r}\text { DeisoPrDehAb*3 } \\
\text { (IV) }\end{array}$ & 9.3 & 4.4 & - & 一 & 一 & - & 11.1 & 9.3 & 5.5 & 2.6 & - & 一 \\
\hline Abietic $\operatorname{acid}(\mathrm{V})$ & 21.8 & 38.4 & 57.3 & 65.6 & 68.0 & 68.1 & 0.1 & 1.4 & 9.5 & 30.3 & 34.3 & 44.7 \\
\hline $\begin{array}{l}\text { Dehydroabietic } \\
\text { acid(VI) }\end{array}$ & 13.2 & 17.7 & 13.6 & 9.7 & 7.1 & 7.2 & 25.8 & 30.3 & 41.4 & 29.4 & 28.2 & 18.5 \\
\hline Neoabietic acid & - & 2.9 & 4.7 & 5.0 & 5.4 & 5.3 & - & - & - & 3.2 & 4.0 & 3.6 \\
\hline
\end{tabular}

*1 Secodehydroabietic acid

*2 Dihydroabietic acid

*3 Deisopropyldehydroabietic acid 
Table-2 Disproportionation reaction of abietic acid with BNDS.

\begin{tabular}{|c|c|c|c|c|c|c|c|c|}
\hline & 13 & 14 & 15 & 16 & 17 & 18 & 19 & 20 \\
\hline $\operatorname{BNDS}(w t \%)$ & 0.5 & 1.0 & 3.0 & 0.5 & 1.0 & 0.1 & 0.5 & 1.0 \\
\hline Reaction temperature & 200 & 200 & 200 & 250 & 250 & 290 & 290 & 290 \\
\hline Reaction time & 4 & 4 & 4 & 4 & 4 & 4 & 4 & 4 \\
\hline seco-DehAb*1 (I) & 14.0 & 23.3 & 28.4 & 16.8 & 22.2 & 2.9 & 14.0 & 18.7 \\
\hline$"$ (II) & 9.4 & 14.4 & 16.5 & 14.4 & 18.1 & 4.0 & 10.1 & 13.3 \\
\hline$" \quad($ total $)$ & $(23.4)$ & $(37.3)$ & $(44.9)$ & $(31.2)$ & $(40.3)$ & $(6.9)$ & $(24.1)$ & $(32.0)$ \\
\hline $\operatorname{DihAb}($ total)*2 (III) & 4.4 & 4.4 & 7.0 & 1.8 & 1.6 & 1.7 & 1.1 & 1.2 \\
\hline $\operatorname{DeisoPrDehAb}^{* 8}(\mathrm{IV})$ & 6.6 & 9.3 & 10.6 & 8.4 & 11.1 & 2.6 & 6.5 & 10.1 \\
\hline Abietic acid (V) & 38.0 & 21.8 & 8.2 & 1.0 & 0.1 & 0.0 & 0.0 & 0.0 \\
\hline DehAb*4 (VI) & 11.9 & 13.2 & 23.1 & 31.3 & 25.8 & 52.3 & 42.1 & 31.6 \\
\hline Neoabietic acid & 1.8 & - & - & - & - & - & 一 & - \\
\hline
\end{tabular}

*1 Secodehydroabietic acid

*2 Dihydroabietic acid

*8 Deisopropyldehydroabietic acid

*4 Dehydroabietic acid

コデヒドロアビエチン酸の占める割合はおのおの $52 \%$ ， 40\%,32\%になっている。この傾向は， 0.5 wt $\%$ BNDS においても同様であった。

触媒量が反応生成物に及ぼす影響も Table-2 から理 解できる。反応温度が $250,290^{\circ} \mathrm{C}$ 亿おいては触媒量が増 加するほどセコデヒドロアビエチン酸の生成量が多くな りそのためデヒドロアビエチン酸拉よびジヒドロアビエ チン酸の生成量法減少している。特に $290^{\circ} \mathrm{C}$ 触媒 0.1 wt\%では脱水素反応が主でありデヒドロアビエチン酸が $52.3 \%$ と半分以上も生成しているが， $290^{\circ} \mathrm{C}$ 触媒 1.0 wt $\%$ では開裂反応が約半分でセコデヒドロアビエチン 酸は $32 \%$ でデヒドロアビエチン酸とほぼ同量になって いる。

反応温度を低くした時, $200^{\circ} \mathrm{C}$ でセコデヒドロアビエ チン酸は反応量の約 $50 \%$ まで増加するが BNDS を多 くしてもそれ以上のセコデヒドロアビエチン酸の増加は 認められなかった。

\section{$2 \cdot 3$ 低温における BNDS の触媒作用}

反応温度 $200^{\circ} \mathrm{C}$ 触媒量 $1.0 \mathrm{wt} \%$ に扝けるアビエチン 酸の加熱反応生成物の経時変化を Fig.-2 に示す。この 図よりデヒドロアビエチン酸の生成量が初期において大 であり以後あまり増加していないことから脱水素反応は 初期にのみ進んでいることが明らかである。またジヒド ロアビエチン酸の生成量が少ないことから水素化反応は ほとんど進んでいないこと，主に開裂反応が進行し55\% のセコデヒドロアビエチン酸と $12 \%$ のデイソプロピル デヒドロアビエチン酸の生成することが認められた。

以上の事実を説明するのに触媒の活性状態として，千 イルラジカルを仮定すると説明しやすい。ジエン構造を 有する反応物からチイルラジカルによる水素引き抜きが 起こり, 生成するチオールの安定な低温条件ではB環の 開裂後, 水素供与が起こり開裂反応が主となる。逆に于

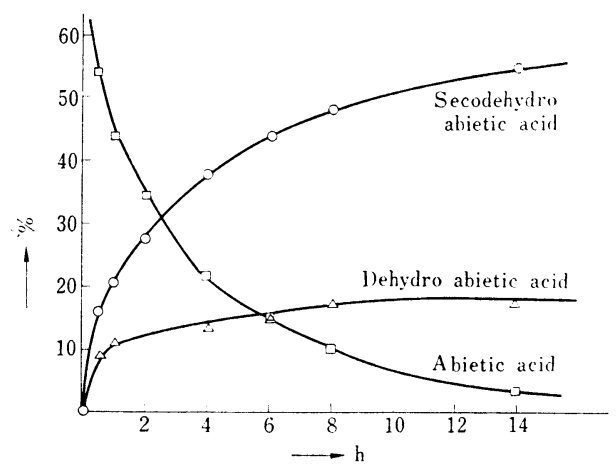

Fig.-2 BNDS catalysed reaction process of abietic acid.

オールの不安定な高温条件下ではチオールは系外に水素 を放出して再度チイルラジカルとして水素引き抜きをし て脱水素反応が主上なると考えるのが妥当であろう。こ れらの開裂, 脱水素及忘は芳香族化による安定化が谁行 を容易にしていると考えられる。

（昭和51年 9 月 20 日受理）

\section{文献}

1) E.E. Fleck, S. Palkin, J. Am. Chem. Soc., 60, 921 (1938)

2) T. Hasselstron et al., J. Am. Chem. Soc., 63, 1759 (1941)

3) P. Kajanne et al., Papperi ja Puu, 39, 377 (1957)

4) 石上雅久, 井上良計, 阿河利男, 油化学, 25, 10 (1976)

5) 石上雅久, 山根耕治, 井上良計, 大城芳樹, 阿河利男, 油化学, 25, 463 (1976)

6) 石上雅久, 并上是計, 大城芳樹, 阿河利男, 油化学, 25, 266 (1976)

7) S.D. Thorpe, U.S. Pat., 3,872,073 (1975)

8) H. Takeda, W.H. Schller, R.V. Lawrence, J. Org. Chem., 33, 3718 (1968)

9) D.F. Zinkel et al., J. Am. Oil Chem.Soc., 46, 633 (1969)

10) E.Jusa, B. Hönigsfeld, Monatsh. Chem., 72, 93(1939)

11) Onuf rowicz, Ber., 23, 3364 (1890) 